\section{Висновки}

У процесі розвитку атласного картографування 3'явилися і нові способи представлення інформації. Атласні інформаційні системи є одним із них. Це вдосконалені електронні атласи 3 фундаментальними властивостями капітальних атласів, які акумулюють усталені, перевірені наукові знання і тому розраховані на багаторазове і багатоцільове використання. Їм притаманні також ознаки оперативних карт-документів, здатних задовольняти швидкомінливі інтереси завдяки можливості інтеграції електронних верств і генерації нових просторових структур, а також використання великої бази даних.

У таких країнах як США, Великобританія, Ка- нада, Німеччина, Японія та інших здійснюється електронне атласне картографування на основі ГІС, у тому числі з метою створення атласних інформаційних систем (на рівні груп країн, для всієї країни або групи іiі економічних районів). Тематичний зміст геоінформаційного картографування також різноманітний (ризики надзвичайних ситуацій, бездомність, природно-заповідний фонд та інші).

В Україні також започатковано процес створення AIC. Їх подальший розвиток пов'язаний зі збільшенням тематичних напрямків дослідження, створенням єдиних систематизованих банків даних та новими способами візуалізації інформації.

\title{
References [Лimepamypa]
}

1. GIS-mapping in Ukraine: conceptual foundations and trends of development. Edited by L.H. Rudenko. (2011). Kyiv: Naukova dumka. [In Ukrainian].

[Геоінформаційне картографування в Україні. Концептуальні основи і напрямки розвитку / За ред. Л. Г. Руденка. - К.: Наукова думка, 2011. - 103 c.]

2. Interactive map Nature reserve fund of Kiev region (2015). http://eko.koda.gov.ua/wp-content/uploads/atlas/maps/themlayers/index. html [In Ukrainian].

[Інтерактивна карта «Природно-заповідний фонд Київської області»(2015). http://eko.koda.gov.ua/wp-content/uploads/atlas/ maps/themlayers/index.html]

3. Kraak M.-J., Ormeling F. (2005). Cartography: visualization of spatial data. Edited by B.C. Tykunova. Moscow: Scientific world. [In Russian].

[Краак М.-Я., Ормелинг Ф. Картография: визуализация геопространственных данных / Под ред. В.С. Тикунова. - М.: Научный мир, 2005. -325 с.]

4. Polyvach K. A. (2016). Regional informational reference Atlas of natural reserve fund. Ukrainian geographical journal, 1, 53-60. [In Ukrainian].

[Поливач К.А. Інформаційно-довідковий атлас природно-заповідного фонду регіону // Укр. геогр. журн. - 2016.- №1. - С. 53-60.]

5. Atlas of Governance and Public Health in Mexico. http://cartografica.mx/ucsd/health

6. Global Freshwater Biodiversity Atlas. http://atlas.freshwaterbiodiversity.eu/index.php/maps?map=1.1.1-global-diversity-patterns

7. PPRD (Prevention, Preparedness, Response to natural and man-made disasters). South Programme Risk Atlas http://www.euromedcp. $\mathrm{eu} / \mathrm{en} / \mathrm{atlas} . \mathrm{html}$

8. Taylor D.R. Fraser (Editor) (2014). Developments In The Theory And Practice Of Cybercartography: Applications And Indigenous Mapping (Modern Cartography. Series 5). Elsevier, 2nd Ed.

Стаття надійшла до редакції 27.10.2016

\author{
УДК 528.92:004.65 \\ doi: $10.15407 /$ ugz2016.04.054 \\ О. М. Лейберюк \\ Інститут географрії Національної академії наук України, Київ

\section{IНТЕРАКТИВНІ ВЕБ-КАРТИ: СУТНІСТЬ І ОСНОВНІ ЕТАПИ СТВОРЕННЯ (НА ПРИКЛАДІ ВЕБ-РЕСУРСУ САRТО)}

Мета цієї публікації полягає в аналізі поняття інтерактивності веб-карт, їх класиффікації та методики створення за допомогою веб-сервісу (CARTO). У тексті статті розглянуто місце засобів веб-картографування поряд з іншими. Проаналізовано сучасний розподіл картографічних веб-ресурсів та класифікацію веб-карт. Розкрито поняття інтерактивності та дано визначення інтерактивних веб-карт. Виділено основні етапи створення інтерактивної вебкарти на сервісі CARTO і дано поетапний опис створення інтерактивної веб-карти чисельності населення Чернівецької області на основі переписів 1959-2001 рр. Новизна роботи полягає у визначенні поняття «інтерактивна веб-карта», опису методики створення веб-карт, виявленні позитивних і негативних сторін при їх створенні.

Ключові слова: веб-картографування; веб-карта; інтерактивність; Carto. 


\begin{abstract}
O. M. Leiberiuk
Institute of Geography of the National Academy of Sciences of Ukraine, Kyiv

INTERACTIVE WEB MAPS: ESSENCE AND THE MAIN STAGES OF CREATION (ON THE EXAMPLE OF THE CARTO WEB RESOURCE)

The purpose of this publication consists in consideration of classification of modern web maps, in the analysis their concept, of interactivity and a methodology of creation of web maps with the help of a cartographical resource (CARTO). The text of the article the position web mapping tools along with other GIS. It is analyzed modern classification of cartographical web resources and web maps. The concept of interactivity is analyzed and given definition of interactive web maps. In the current article is represented the main stages of interactive web map creation on the CARTO service. Furthermore, the present article gives the stage-by-stage description of the web map creation, on the example of Chernivtsi region population which based on censuses of 1959-2001 years. Novelty of this work consists in definition of a concept the interactive web map, descriptions of the creation web map, identification of positive and negative sides during creation of web cards.
\end{abstract}

Keywords: web mapping; web map; interactivity; Carto.

\section{Актуальність дослідження}

Інформатизація суспільства, впровадження нових технологій та наростання обсягу інформації активізують процеси аналізу існуючих та створення нових інформаційних продуктів. За оцінками експертів ООН, близько 80\% інформації, яка використовується у сучасному самоврядуванні та державних органах високорозвинених країн, має геоприв'язку та може бути використана як геопросторові дані [6]. Нині найбільшим місцем їх збору, концентрації, розповсюдження, а також можливості їх обробітку, аналізу та представлення є Глобальна мережа.

У руслі сучасної геоінформаційної концепції розвивається і картографія, що також відбивається у можливостях використання web-pecyрсів.

Теоретичні обгрунтування концепції геоінформаційного картографування, сутності електронних карт викладені в працях О.М. Берлянта, Л.Г. Руденка, Д.О. Ляшенка, Е.Л. Бондаренка, М.-Я. Краака, Ф. Омерлінга, С. Стейнігера [1, 2, 5-9] та інших.

М е т а цієї публікації полягає в аналізі поняття інтерактивності веб-карт, їх класифікації та методики створення за допомогою веб-сервісу (CARTO). Цей аналіз базується на вивченні попередніх робіт, зокрема названих авторів, а також на класифікації карт Всесвітньої мережі та інших.

\section{Виклад основного матеріалу}

3 початком епохи розвитку ГІС (60-х рp. XX ст.) донині розвиток геоінформаційного напрямку зазнав великих змін, що відобразилось у методиці, способах створення карт, теорії та практиці застосування картографічних творів, що базується на концепції геоінформаційного картографування[7]. 3 огляду на цю концепцію карти є частиною різновиду загальної сукупності геозображень. За О.М. Берлянтом, геозображення (geoimage, georepsentation) - це будь-яка просторово-часова, масштабна, генералізована модель земних або планетарних об'єктів та процесів, представлена у графічно-образній формі [1].

Це поняття є широким та охоплює великий масив різноманітних картографічних творів і не тільки. Тому, на нашу думку, слід вживати більш конкретне поняття для карт, створених за допомогою певних машинно-програмних продуктів. Таким може слугувати поняття «електронна карта», під яким розуміють векторну або растрову карту, сформовану на машинному носії $з$ використанням програмних і технічних засобів у прийнятій проекції, системі координат, умовних знаках, призначеної для аналізу і моделювання, а також вирішення інформаційних і розрахункових завдань за даними щодо місцевості та природних умов [6].

Створення та розповсюдження електронних карт зумовлюється ступенем знань користувача, цілями картографування, кінцевою метою та необхідністю формату представлення. Для цих цілей використовують різноманітні ГІС, які виділяють за своїм функціоналом: настільні, мобільні, WebGIS клієнти, GIS-сервіси, Системи просторового управління базами даних, програмні бібліотеки / GIS розширення, WMS(Web Map Server) [8].

Оскільки нині Глобальна мережа є основною базою для створення, розповсюдження, перегляду різноманітної інформації, актуальним питанням $\epsilon$ способи створення і зображення карт у Глобальній мережі, які нині широко застосовуються не тільки географами та картографами, а й іншими суспільними групами (журналістами, громадськими організаціями та активістами, програмістами, екологами та іншими). Можливість створення таких карт мають усі зацікавлені, що мають доступ до Глобальної мережі.

Геоінформаційні системи 3 можливістю картографування в мережі Інтернет (засоби веб-картографування) - це програмне забезпечення, призначення якого полягає у побудові геокоординованих даних в мережі Інтернет [2]. Сюди також відносяться веб-сервіси, що дозволяє переглядати, редагувати й створювати нові геопросторові дані.

За призначенням їх класифікують на такі види:

1) SaaS, програмне забезпечення, доступне як сервіс у мережі Інтернет (ArcGIS Online, Carto, MapBOX); 
2) $\mathrm{PaaS}$, веб-платформи для геокодування, аналізу та обробки (Google Maps JavascriptAPI version, Microsoft Bing Geocode Data-flow API, US Census Geocoder);

3) DaaS, сервіси даних та контент послуг (Appel Maps, Google Maps, Open Street Maps, Bing Maps, Яндекс Карты та інші) [9].

Кінцевим результатом використанням цих продуктів $\epsilon$ відображення електронних веб-карт або частіше вживаному понятті веб-карт (web maps), що за своєю суттю не відрізняється від поняття електронної карти, а приставка веб(web) характеризує тільки основний спосіб створення та (або) зображення таких карт.

За характерними особливостями веб-карти, у широкому розумінні, поділяють на динамічні та статичні. Слід зазначити, що в кожній з вищезгаданих категорій виділяють карти неінтерактивного та інтерактивного (динамічного) характеру [5].

Найпоширеніші неінтерактивні карти, хоча дедалі важче простежувати їх співвідношення 3 інтерактивними, які забезпечують можливість тільки перегляду, до них відносяться всі карти, створені до комп'ютерної епохи картографування, або ті, що створені за допомогою комп'ютерних технологій у вигляді статичних зображень.

Інтерактивні (англ. interactive - взаємодіючий, діалоговий; для систем обробки інформації - такий, що характеризує систему або режим роботи, для яких притаманним $є$ відгук на команди оператора [3]) карти характеризуються як система взаємодії користувача та карти, де діє принцип користувач (запит) $\leftrightarrow$ система (відповідь). Інтерактивні веб-карти - це електронні зображення, які являють собою геодані певних характеристик або явищ, розміщених на сервері, що відображаються як геозображення у вікні браузера та можуть змінюватись та відповідати, за певних умов, на запити користувача.

Інтерактивні карти можуть мати властивості динамічності зображення, гіперпосилань, змінювати масштаб, генералізацію, кількість шарів зображення та багато інших можливостей, що на сьогодні реалізується за допомогою різноманітних мов програмування.

Зростання кількості та різноманітності вебкарт призвело до створення ширшої класифікації, що включає: аналітичні веб-карти (analytical web maps), анімовані (animated web maps) та в режимі реального часу (realtime web тарs), спільні (загальнодоступні) веб-карти (collaborative web-maps), онлайн атласи (online atlases), статичні веб-карти (static web maps) [8], для яких характерна як інтерактивність, так і неінтерактивні відображення.

Нами було розглянуто можливості використання програмного забезпечення хмарних обчислень картографічної веб-платформи Carto [4] для створення інтерактивної веб-карти «Чисельність населення Чернівецької області на основі перепису 2001 р.». Платформа CARTO (раніше Carto DB) $\epsilon$ програмним забезпеченням, доступним як платформа обчислень, що використовує функції ГІС і картографічних веб-інструментів для зображення веб-карт у браузері. Стартом роботи цієї платформи $€ 2011$ p., вона $€$ «умовно безкоштовною» та працює як «freemium service», що дозволяє публікацію 5 карт безкоштовно та зберігання 250 МБ векторних даних. Великим недоліком безкоштовного профілю $є$ відсутність приватності даних щодо карт та даних, які можуть бачити та використовувати всі користувачі.

Загалом технологія функціонування сервісу Carto, яку бачить користувач і за допомогою якої будують карти, базується на програмному забезпеченні з відкритим вихідним кодом, що охоплює систему керування базами даних та підтримки географічних об'єктів PostgreSQL i PostGIS, візуалізаційну частину, побудовану за допомогою JavaScript (з широким використання iї бібліотек); відображення карт відбувається за допомогою програм Mapnik, Leaflet/Gmaps.

Увесь процес створення інтерактивних карт можна розділити на три етапи (рис.1):

1) підготовчий (збір, формування і редагування бази даних);

2) завантаження (завантаження даних та доопрацювання);

3) вивід і представлення результатів.

На першому етапі слід обгрунтувати та чітко визначити об'єкт картографування і способи візуалізації, але перед цим бажано ознайомитись із функціональними прикладами сервісу, прикладами візуалізації, визначити види форматів, які підтримує та $з$ якими працює платформа.

У нашому випадку об'єктом зображення $є$ чисельність сільського та міського населення та щільність населення у розрізі адміністративних одиниць. Щодо форматів підтримки, то цей сервіс підтримує завантаження з пристрою клієнта (desktop), використання даних 3 інших Інтернет платформ (Google Drive, Dropbox, Twitter, ArcGIS Server та інших), використання баз даних інших користувачів сервісу, якщо вони є публічними. Основними форматами, які можна відвантажувати, $\epsilon$ CSV, XVS, ZIP, KML, GPX. Точкові об'єкти були оформлені у табличній формі в форматі CSV. Слід зазначити, що ці дані можуть бути створенні у системі керування базами даних, табличному, текстовому редакторі, однак із необхідністю наявності координат прив'язки.

Для полігональних об’єктів використано SHPфайл адміністративних одиниць Чернівецької області, що разом із додатковими файлами мають 


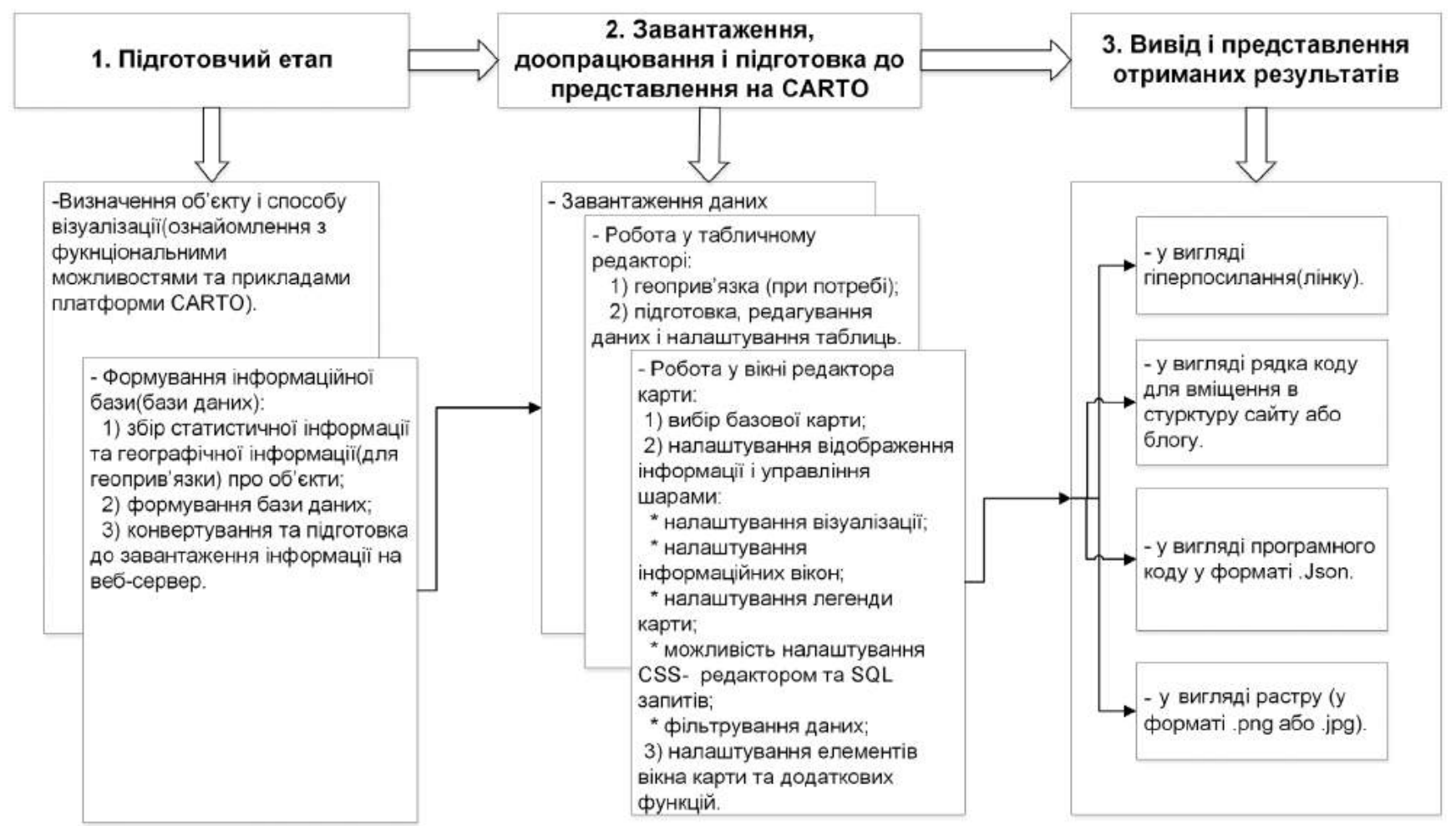

Рисунок 1. Основні етапи та дії при створенні карти на сервісі CARTO

бути заархівовані у ZIP-файл. Для їх створення та редагування виникає потреба використання ГIC-пакету.

Наповненість бази даних атрибутивною інформацією має свою особливість - для точкових об'єктів, було визначено такі основні характеристики: назва українською мовою, назва англійською мовою, чисельність населення у 1959, 1970, 1979, 1989, 2001 рр., географічна широта та довгота населеного пункту; для полігональних об'єктів: назва адміністративної одиниці та щільність населення на 2001 p.

На другому етапі здійснено завантаження та редагування інформації. Можна виділити дві області для роботи із даними. Як і у звичних ГІС програмах, виділяється табличний атрибутивний редактор та вікно карти.

У табличному редакторі $є$ можливість простих дій із даними та їх редагуванням: додавання тексту, посилань та інших особливостей, можливість редагування даних таблиці. Однак при роботі із точковими об'єктами є необхідність їх геоприв'язки (Georeference) за допомогою довготи та широти, географічної назви об' єкта, поштового індексу або IP-адреси.

У вікні карти є можливість вибору базової карти, налаштування вікна та елементів відображення, можливість додавання тексту та зображень. У цьому вікні безпосередньо відбувається і налаштування карти за допомогою бокової панелі, що дозволяє здійснювати вибір об'єктів зображення, способу та його налаштування, особливостей відображення інтерактивності карти, роботи із SQL запитами, а також безпосереднє редагування коду зображення на мові програмування CSS, що переважно використовується для відображення на веб-сторінках. Також є можливість створення багатошарової карти.

Кінцевий етап - це власне виведення веб-карти, яку можна отримати у вигляді звичайного растрового зображення, посилання (гіперпосилання) або у вигляді відкритого коду у форматі GeoJSON 3 подальшим його використанням.

3 результатом роботи можна ознайомитись за посиланням: https://sashalom.carto.com/viz/507039f03d1d-11e6-aadc-0e31c9be1b51/embed_map

\section{Висновки}

Інтерактивні карти є одними із найдинамічніших видів карт, що нині розвиваються, насамперед веб-карт. Класифікація та розподіл веб-карт зумовлюються сферами застосування, якісними їх характеристиками та доступністю.

Інтерактивні веб-карти являють собою системи зв'язків між користувачем та сервером за допомогою мережі Інтернет, результатом якої є відображення карти або інформації у вікні браузера.

Створення та використання інтерактивного веб-картографування та веб-карт є потрібним, важливим та актуальним, однак воно має свої позитивні та негативні сторони.

До позитивних слід віднести можливість роз- 
повсюдження та роботи з даними у мережі Інтернет, скорочення часу на підготовку та відображення, створення інтерактивно-привабливої електронної карти, що легко читається, та можливість аналізу даних за допомогою різних засобів. Ці характеристики можуть розширюватись і змінюватись.

Негативними сторонами можна вважати неповноту та обмеженість використання усієї повноти картографічного методу пізнання, що обмежується можливостями сервісної та програмної частини, необхідність володіти уміннями програмування, залучення фінансування при частому використанні та при роботі з великими обсягами даних.

У підсумку можна зазначити, що веб-картографування є одним із майбутніх векторів розвитку ГІС-технологій та Всесвітньої мережі, що нині спостерігається та має великі можливості й перспективи.

Новизна цього дослідження полягає в докладному аналізі поняття інтерактивності та визначенні поняття інтерактивних веб-карт, представленні методики та етапності створення веб-карт за допомогою веб-ресурсів, яка може бути використана в різних галузях та сферах діяльності суспільства.

\section{References [Лimepamypa]}

1. Berlyant A.M. (2006). Theory geoimages. Moscow: GEOS. [In Russian].

[Берлянт А.М. Теория геоизображения. - Москва: ГЕОС, 2006. - 262 с.]

2. Bondarenko E.L., Shevchenko V. O., Ostrouh V. I. (2005). Geoinformation bases of eco-geographical mapping. Kyiv: Fitosotsiotsentr. [In Ukrainian].

[Бондаренко Е. Л., Шевченко В.О., Остроух В.І. Геоінформаційні основи еколого-географічного картографування. - Київ: Фітосоціоцентр, 2005. - 116 c.]

3. Great Dictionary of Modern Ukrainian. Head. ed. V. T. Busel. (2005). Kyiv : Irpin: PTC Perun. [In Ukrainian].

[Великий тлумачний словник сучасної української мови / Голов. ред. В. Т. Бусел. — К.: Ірпінь: ВТФ «Перун», 2005. — 1728 с.]

4. Cartographic web platform Carto. https://carto.com/ [In Ukrainian].

[Картографічна веб-платформа Carto. https://carto.com/ ]

5. Kraak M.- J., Ormeling F. (2005). Cartography: visualization of geospatial data. Translation by ed. V. S. Tikunov: Moscow. Scientific World. [In Russian].

[Краак М.-Я., Ормелинг Ф. Картография: визуализация геопространственных данных / перевод под. ред. В.С. Тикунова Москва: Научный мир, 2005. - 324 с.]

6. Lyashenko D. O. (2008). Cartography topography with the basics: A manual for high schools. Kyiv: Naukova dumka. [In Ukrainian]. [Ляменко Д.О. Картографія з основами топографії: Навчальний посібник для вищих навчальних закладів. - К.: Наукова думка, 2008. - 184 с.]

7. Rudenko L.H., Kozachenko T.I., Lyashenko D.O., Bochkovska A.I. (2011). Geoinformation mapping in Ukraine: conceptual framework and direction of development. Kyiv: Naukova dumka. [In Ukrainian].

[Геоінформаційне картографування в Україні: концептуальні основи і напрямки розвитку / Л. Г. Руденко, Т. І. Козаченко, Д.О. Ляшенко, А. І. Бочковська. - К.: НВП Вид.«Наукова думка», 2011. - 104 с.]

8. Steiniger S., Robert W. (2009). GIS Software. A description in 1000 words. https://sourceforge.net/projects/jump-pilot/files/w_other_ freegis_documents/articles/gissoftware_steiniger2008.pdf/download

9. Steiniger S., Hunter A.. The 2012 Free and Open Source GIS Software Map. A Guide to facilitate Research, Development and Adoption. http://www.geo.uzh.ch/ sstein/manuscripts/fosgismap_sstein_v9_web.pdf

10. Zeiler M. (2004). Modeling Our World. ESRI Handbook on designing geodatabase: Trans. from English. Kyiv: ESOMM Company Co. [In Russian].

[Зейлер M. Моделирование нашего мира. Пособие ESRI по проектированию баз геоданных: Пер. с англ. - К.: 3АО ЕСОММ Co., 2004].

Стаття надійшла до редакції 7.11.2016 